\title{
Method for flow cytometric monitoring of Renibacterium salmoninarum inactivation
}

\author{
R. J. Pascho ${ }^{1, *}$, J. E. Ongerth ${ }^{2}$ \\ ${ }^{1}$ U.S. Geological Survey, Biological Resources Division, Western Fisheries Research Center, 6505 N.E. $65^{\text {th }}$ Street, Seattle, \\ Washington 98115 , USA \\ ${ }^{2}$ School of Civil and Environmental Engineering, The University of New South Wales, Sydney, New South Wales 2052 , \\ Australia
}

\begin{abstract}
The slow growth of Renibacterium salmoninarum limits the usefulness of culture as a research tool. Development of a 2-color flow cytometric assay to quantify the proportions of live and dead $R$. salmoninarum in a test population is described. Bacteria were simultaneously stained with fluorescein isothiocyanate-conjugated immunoglobulin and exposed to the exclusion dye propidium iodide. Propidium iodide red fluorescence profiles of control groups of untreated and killed $R$. salmoninarum were compared with those for bacteria exposed to chlorine. Bacterial inactivation was based on mean red fluorescence intensity, and analyzed by high-red fluorescence intensity (HRFI) and curve subtraction (CS) analyses. When the concentration of $R$. salmoninarum was $8.65 \times 10^{6}$ bacteria $\mathrm{ml}^{-1}$ and the bacteria exposed to chlorine at $1 \mathrm{mg} \mathrm{l}^{-1}$ for periods from 1 to $20 \mathrm{~min}$ (high-Rs assessment), the mean red fluorescence intensity of the profile for each chlorine-exposure group was higher than that for the untreated control $(\mathrm{p}<0.0001)$. When the concentration of $R$. salmoninarum was reduced to $1.76 \times 10^{6}$ bacteria $\mathrm{ml}^{-1}$ and exposed to $0.8 \mathrm{mg} \mathrm{l}^{-1}$ free chlorine level for periods from $20 \mathrm{~s}$ to $5 \mathrm{~min}$ (reduced-Rs assessment), the mean red fluorescence intensities of the exposure groups were higher than that for the untreated control only when the $R$. salmoninarum was exposed to chlorine for at least 1 min $(p \leq 0.01)$. On the basis of red fluorescence intensity, the proportion of dead cells generally increased with the duration of chlorine exposure. Whereas the rates of inactivation derived from the HRFI and CS analyses did not correlate with the duration of exposure in the high-Rs assessment $\left(\mathrm{r}^{2} \leq 0.27\right)$, there was a correlation between these estimates and the duration of exposure in the reduced-Rs assessment $\left(\mathrm{r}^{2} \geq 0.92\right)$. Because of the rapid loss of culturable $R$, salmoninarum in both assessments following chlorine exposure, neither the duration of exposure nor the inactivation estimates correlated with bacteriological culture $\left(\mathrm{r}^{2} \leq 0.22\right)$. In both assessments, there was a correlation between the estimates of inactivation based upon HRFI and CS analyses $\left(r^{2}>0.99\right)$. These results suggest that flow cytometry can be used as a supplementary or alternative method to bacteriological culture for monitoring the inactivation of $R$. salmoninarum.
\end{abstract}

KEY WORDS: Renibacterium salmoninarum - Flow cytometry · Viability assay · Propidium iodide . Chlorine

\section{INTRODUCTION}

Renibacterium salmoninarum is the causative agent of bacterial kidney disease (BKD) in wild and cultured salmonid fishes worldwide (Fryer \& Sanders 1981). This Gram-positive bacterium may be transmitted vertically (Bullock et al. 1978, Evelyn et al. 1986b), but healthy susceptible fish can also become infected by

•E-mail: ron_pascho@usgs.gov waterborne $R$. salmoninarum (Mitchum \& Sherman 1981, Bell et al. 1984). The disease is usually chronic, and mortality from BKD occurs among juvenile and adult fish in both fresh and salt water.

The chronic nature of the disease and the existence of more than one mode of transmission make BKD one of the most difficult bacterial fish diseases to control. Methods currently used to interrupt the cycle of vertical transmission include the injection of prespawning adult salmon with erythromycin phosphate (Bullock \& 
Leek 1986, Evelyn et al. 1986a) and brood stock segregation (Elliott et al. 1989, Pascho et al. 1991). Horizontal transmission of Renibacterium salmoninarum to healthy fish is thought to occur while they are residing in the same water supply as infected fish. This is of great importance in hatcheries because salmon and trout are often reared in untreated river or ground water, or in the absence of adequate water sources, in recirculation systems. River water may contain resident species of fishes that are known to be susceptible to $R$. salmoninarum, or in many cases, progeny of fish from infected hatchery stocks which were allowed to spawn naturally in the river. In a water reuse hatchery, the probability of horizontal transmission is greatly increased if $R$. salmoninarum shed from the infected fish is repeatediy cycied pasi the hedilhy fishi. Although the use of pathogen-free well or spring water would be most desirable, it may also be possible to disinfect or sterilize surface water. Methods to disinfect or sterilize water for fish culture include ozone, oxidizing agents, filtration, heat, ultraviolet light, quaternary ammonium compounds, and chlorine as a gas or solution (Dupree 1981, Wedemeyer 1996). There are only a few reports describing the inactivation of $R$. salmoninarum by antimicrobial compounds; iodine (Ross \& Smith 1972), ozone (Wedemeyer \& Nelson 1977, Wedemeyer et al. 1978), and chlorine (Pascho et al. 1995) are effective against the bacterium.

Laboratory studies examining antimicrobial treatments to interrupt vertical and waterborne transmission of Renibacterium salmoninarum have created a need to rapidly distinguish living from dead bacterial cells. The enzyme-linked immunosorbent assay (Pascho \& Mulcahy 1987. Turaga et al. 1987) and the fluorescent antibody test (Bullock et al. 1980, Elliott \& Barila 1987) are typically used to quantify the prevalence and levels of $R$. salmoninarum, but neither detection method can distinguish live from dead bacteria. Unfortunately, bacteriological culture is the only method currently available to quantify the proportion of viable bacteria in a population of $R$. salmoninarum. The slow growth of the bacterium, with incubation periods as long as $19 \mathrm{wk}$ for growth on an agar medium (Benediktsdottir et al. 1991), can create substantial delays in the interpretation of experimental results.

Alternative methods have been reported for differentiating between dead and injured or living bacterial cells (Roszak \& Colwell 1987, Calabrese \& Bissonnette 1990, Desmonts et al. 1990, Singh et al. 1990, Byrd et al. 1991). Lethal injury of a microorganism by physical or chemical treatment is based on the severity of both the structural injury to the permeability barrier and the metabolic injury to the functional components (Ray 1979). If the lethal effects of an antimicrobial compound are initiated by damage to the cell wall, it may be possible to use an exclusion dye to distinguish cells with a lethal injury. Such dyes are considered viability stains because they do not enter cells with intact membranes and the absence of staining is considered indicative of a live cell.

Propidium iodide (PI) is a basic dye that binds to DNA and double-stranded RNA, yet is excluded by intact membranes (Parks et al. 1986, Shapiro 1988). PI staining can be used in conjunction with flow cytometry (FC) to create a rapid, quantitative fluorescence assay to describe the viability characteristics of a population of organisms. Analysis of the measurements permits one to distinguish unique or changing physical and chemical properties of a cell population. Although FC is commonly used in the analysis of eucaryotic cells, particularily in the field of immunology, it is now gaining wider use in bacterial studies. Fluorescence FC using PI has been used to identify bacteria in heterogeneous populations (Van Dilla et al. 1983, Miller \& Quarles 1990), to monitor bacterial growth (Boye \& Løbner-Olesen 1991), and to assess viability (Jepras et al. 1995, Nebe-von Caron et al. 1998). The ability of FC used in conjunction with PI and other fluorescent dyes to rapidly distinguish between live and dead bacteria has been used successfully to detect bacteria in viable but dormant, nonculturable states (Thorsen et al. 1992) and to monitor bacterial injury from antibiotics (Suller \& Lloyd 1999) or survival following different lethal treatments (López-Amorós et al. 1995).

This report describes the development of a 2-color immunofluorescence flow cytometric assay to quantify the proportions of live and dead Renibacterium salmoninarum in a treatment population. Results from monitoring the inactivation of $R$. salmoninarum by chlorine suggest that $\mathrm{FC}$ can be used as an alternative or supplementary method to bacteriological culture in laboratory studies assessing the efficacy of antimicrobial compounds with this bacterium.

\section{MATERIALS AND METHODS}

Bacterial strain and growth conditions. A stock isolate of Renibacterium salmoninarum (ATCC 33209) was grown in KDM 2 broth (Evelyn 1977) as described by Pascho et al. (1995). The bacterial cells were washed 3 times, and on the basis of cell counts by the membrane-filtration fluorescent antibody test (MF-FAT), adjusted to the appropriate concentration in chlorine-demand-free $0.01 \mathrm{M}$ phosphate-buffered saline (PBS) pH $7.0\left(\mathrm{NaH}_{2} \mathrm{PO}_{4}-\mathrm{Na}_{2} \mathrm{HPO}_{4}\right.$ phosphate buffer in distilled-deionized water [Nanopure II; Barnstead Co., Newton, MA, USA]).

Quantification of bacteria by the MF-FAT. The concentration of Renibactenum salmoninarum cells in the 
washed preparation was determined by the MF-FAT of Elliott \& Barila (1987), as described by Pascho et al. (1995)

Fluorescent stains and microbeads. Affinity-purified goat immunoglobulin to Renibacterium salmoninarum conjugated with fluorescein isothiocyanate (FITC-IgG Kirkegaard and Perry Laboratories, Inc., Gaithersburg, MD, USA) was used for the MF-FAT, and the flow cytometric procedures described below. The FITC-IgG was filtered through a $0.2 \mu \mathrm{m}, 13 \mathrm{~mm}$ polycarbonate filter (Nuclepore, Pleasanton, CA, USA) before use for the MF-FAT, or a $0.2 \mu \mathrm{m}$, polyvinylidene difluoride filter (Millipore, Bedford, MA, USA) before use in FC. Filtered conjugate was adjusted to the appropriate dilution in 0.01 M PBS pH 7.4.

A stock solution of propidium iodide ( $\mathrm{PI}$; Sigma Chemical Co., St. Louis, MO, USA) at $200 \mu \mathrm{g} \mathrm{m}^{-1}$ was prepared in $0.01 \mathrm{M}$ PBS pH 7.4 and aliquots were frozen at $-70^{\circ} \mathrm{C}$. To determine the proportion of dead Renibacterium salmoninarum cells in a treatment group, the bacteria were stained with a volume of freshly thawed stock PI solution at a final concentration of $5 \mu \mathrm{g} \mathrm{ml}^{-1}$

Concentrated Fluoresbrite carboxylate beads $(5.75 \pm$ $0.12 \mu \mathrm{m}$; Polysciences, Inc., Warrington, PA, USA) were diluted $1: 24(\mathrm{v} / \mathrm{v})$ in sterile Nanopure water and centrifuged at $1000 \times g$ for $10 \mathrm{~min}$ at $4^{\circ} \mathrm{C}$. The pellet was resuspended in $25 \mathrm{ml}$ sterile Nanopure water and stored at $4^{\circ} \mathrm{C}$. To determine the concentration of beads in the final suspension, a $1 \mathrm{ml}$ volume of the resuspended beads diluted to $1: 1000(\mathrm{v} / \mathrm{v})$ in PBS-Triton was filtered through a $0.2 \mu \mathrm{m}, 13 \mathrm{~mm}$ diameter polycarbonate membrane filter (Nuclepore, Pleasanton, CA, USA). The filter was examined with a fluorescence microscope and the bead concentration was calculated as described for the enumeration of bacteria.

Preparation of chlorine test solutions. A stock solution of sodium hypochlorite $(5.2 \%$ active ingredient; J. T. Baker, Phillipsburg, NJ, USA) was prepared as described by Pascho et al. (1995) such that the free chlorine concentration was $40 \mathrm{mg} \mathrm{l}^{-1}$. The free residual chlorine in the control and bacterial treatment solutions was neutralized with the appropriate volume of sterile $1 \%(\mathrm{w} / \mathrm{v})$ sodium thiosulfate (Sigma Chemical Co., St. Louis, MO, USA).

Chlorine determinations. The free chlorine residual of the stock sodium hypochlorite solutions and treatment solutions were determined by the $N, N$-diethyl- $p$ phenylenediamine (DPD) colorimetric method (American Public Health Association 1989).

General experimental procedure for chlorine exposures. After the washed Renibacterium salmoninarum were adjusted to the appropriate concentration in $0.01 \mathrm{M}$ PBS, they were exposed to chlorine according to the general method described by Pascho et al.
(1995). Briefly, equal volumes of a bacterial preparation were placed in 2 stirred flasks and equilibrated to $15^{\circ} \mathrm{C}$ in an incubator or a chilled, circulating water bath. A prescribed volume of a stock chlorine solution equilibrated to $15^{\circ} \mathrm{C}$ was added to one of the stirring flasks. After each exposure period, a $10 \mathrm{ml}$ volume was removed and neutralized by the addition of $100 \mu \mathrm{l}$ of $1 \%(\mathrm{w} / \mathrm{v})$ sodium thiosulfate. Subsamples of control bacterial preparations and bacteria from the neutralized chlorine treatments were then cultured on agar plates as described above. In a separate study, 0.01\% (w/v) sodium thiosulfate did not inactivate $R$. salmoninarum as determined by bacteriological culture and flow cytometry (data not shown). The concentration of free chlorine was measured over the duration of an experimental exposure in the second flask of bacteria after addition of the same concentration of chlorine as was used for the experiment; the bacteria were removed from each sample by passing the suspension through a $0.2 \mu \mathrm{m}$ polysulfone membrane filter (Gelman Sciences, Ann Arbor, MI, USA), and the free chlorine concentration was measured immediately.

Reference bacterial preparations. In addition to the chlorine exposure groups, each procedure also contained 2 reference groups of Renibacterium salmoninarum that aided in interpreting the results of an analysis. They were untreated bacteria, and a corresponding bacterial preparation that had been heated at $80^{\circ} \mathrm{C}$ for $20 \mathrm{~min}$ to represent $100 \%$ inactivation. The red fluorescence intensity profile for untreated bacteria was centered near channel 60 on the 1 to 200 scale (log) and represented $100 \%$ viability. The corresponding profile for an identical bacterial preparation heated at $80^{\circ} \mathrm{C}$ for $20 \mathrm{~min}$, typically located near channel 120 , represented $100 \%$ inactivation.

Final procedure for FC. An Ortho Cytofluorograph $50 \mathrm{H}$ with a model 2150 computer (Ortho Diagnostic Systems, Westwood, MA, USA) was used for this study. The FITC and PI were excited at $488 \mathrm{~nm}$ with a model 164-05 argon ion laser (Spectra Physics, Mountain View, CA, USA).

For FC, a constant number of the $5.75 \mu \mathrm{m}$ fluorescent microspheres were added to the control and treatment groups, then the bacterial cells were simultaneously stained with FITC-IgG and PI for $60 \mathrm{~min}$ in a $15^{\circ} \mathrm{C}$ circulating water bath. After incubation with the fluorescent dyes, the bacteria were held on ice until they were analyzed.

During flow cytometric analysis, individual areas from the 2-parameter histograms of forward versus right angle light scatter were selected that represented the microspheres and the bacteria. To standardize the analyses among treatment groups, data were collected for the red fluorescence intensity of bacteria that passed the detector during the period required to 
detect a predetermined number of microspheres. Both the microspheres and the bacteria were counted based on FITC emissions detected with a 525/30 nm emission filter, and the red fluorescence of the PI emissions was detected with a $600 \mathrm{~nm}$ long-path emission filter. The red fluorescence of each cell was simultaneously measured and included in a profile describing the relative red fluorescence distribution for all of the cells analyzed from a given experimental suspension.

Reference bacterial viability assays. The numbers of viable Renibacterium salmoninarum in each control and experimental bacterial preparation were determined by bacteriological culture. Samples were cultured at $15^{\circ} \mathrm{C}$ for $30 \mathrm{~d}$ after inoculation onto plates of a charcoal agar medium (Daly \& Stevenson 1985) suppiemented with $1.5 \%$ ivivj of the celi-íree supernalani of KDM 2 broth which had been used to grow $R$. salmoninarum for $14 \mathrm{~d}$ at $15^{\circ} \mathrm{C}$ (Evelyn et al. 1990). Each inoculum consisted of a $100 \mu$ volume of undiluted bacteria, or of material from one or two 10-fold dilutions of bacteria in peptone-saline, that was evenly dispersed with a glass spreader over the surface of the agar medium in each of 4 petri dishes.

Bacterial inactivation measured by FC. For FC, the relative positions of profiles for groups of bacteria exposed to chlorine under different experimental conditions were analyzed using the locations of the untreated and inactivated control profiles as reference points. Two methods were used to determine the proportion of dead cells:

(1) High red fluorescence intensity (HRFI) method based upon the heat-control group. A bacterial cell was considered dead if it produced a red fluorescence that exceeded channel 100 on a histogram of red fluorescence intensity. The proportion of inactivated bacterial cells in each replicate of a treatment group was then calculated on the basis of the corresponding replicate of the heat-control group.

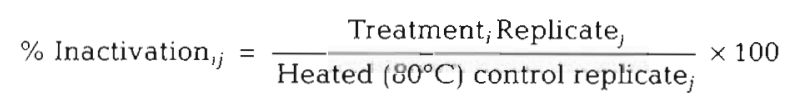

(2) Curve subtraction (CS) analysis method based upon untreated control group. Each replicate of the heat control group and of the chlorine treatment groups was compared to the corresponding replicate of the untreated control group with the Multiple Option Two Parameter Analysis program (Phoenix Flow Systems, San Diego, CA, USA). The area of the control profile was subtracted from that of the corresponding treatment group and the remaining cells were considered dead. The program compensated for differences in the total number of cells evaluated in each replicate subgroup within a given comparison. The proportion of inactivated bacterial cells in each replicate of a treatment group was then calculated on the basis of the corresponding replicate of the heat-control group according to the formula given above.

For direct comparison of FC data to bacterial plate assays, a means of establishing an accurate measure of concentration (number per unit volume) was required for FC-processed samples. The FC analysis produces counts that can only be interpreted as proportions of live and dead categories. A reduction in organism concentration due to disintegration would not be revealed using such a procedure. It is difficult to verify volumes or flowrates directly from flow cytometer operating data. Accordingly, we added a selected volume of a suspension containing precisely defined numbers of fluorescent microspheres, readily distinguishable from target organisms by size. Counts of target organisms were hen coñtiolled by counting a fixed nimber of fluorescent microspheres.

Data analysis. Dunnett's test was used for the pairwise comparisons of the mean bacterial count for the untreated control to the mean bacterial count for a given treatment group. Pairwise comparisons of the mean red fluorescence intensities for groups of untreated bacteria and those for a given treatment group were done by the Scheffé's F-test. To determine if a correlation existed between the results from different measures of bacterial inactivation, a coefficient of determination $\left(\mathrm{r}^{2}\right)$ was calculated between the duration of exposure and individual viability estimates, or pairwise among the various viability estimates.

\section{RESULTS}

\section{Population selection}

Rapid differentiation of live and dead bacterial cells by FC was evaluated by use of suspensions of Renibacterium salmoninarum exposed to either a lethal heat treatment, or to various concentrations of chlorine. Initially, 2 light scatter measurements were used to select the bacteria for which the relative viability was assessed by measuring the red fluorescence of PI. Results were encouraging when intact cells killed by heat and stained with PI were tested by fluorescence microscopy and FC. However, the ability of the forward scatter and right angle $\mathrm{FC}$ measurements to resolve $R$. salmoninarum from background events was compromised by the relatively small size of the bacterium $(0.3-0.5 \mu \mathrm{m}$ by $0.1-1.0 \mu \mathrm{m})$. Machine settings required for these analyses with the Ortho $50 \mathrm{H}$ flow cytometer made it difficult to distinguish the bacterium from electronic noise and events recorded presumably because of other material not related to the bacterium (Fig. 1). 


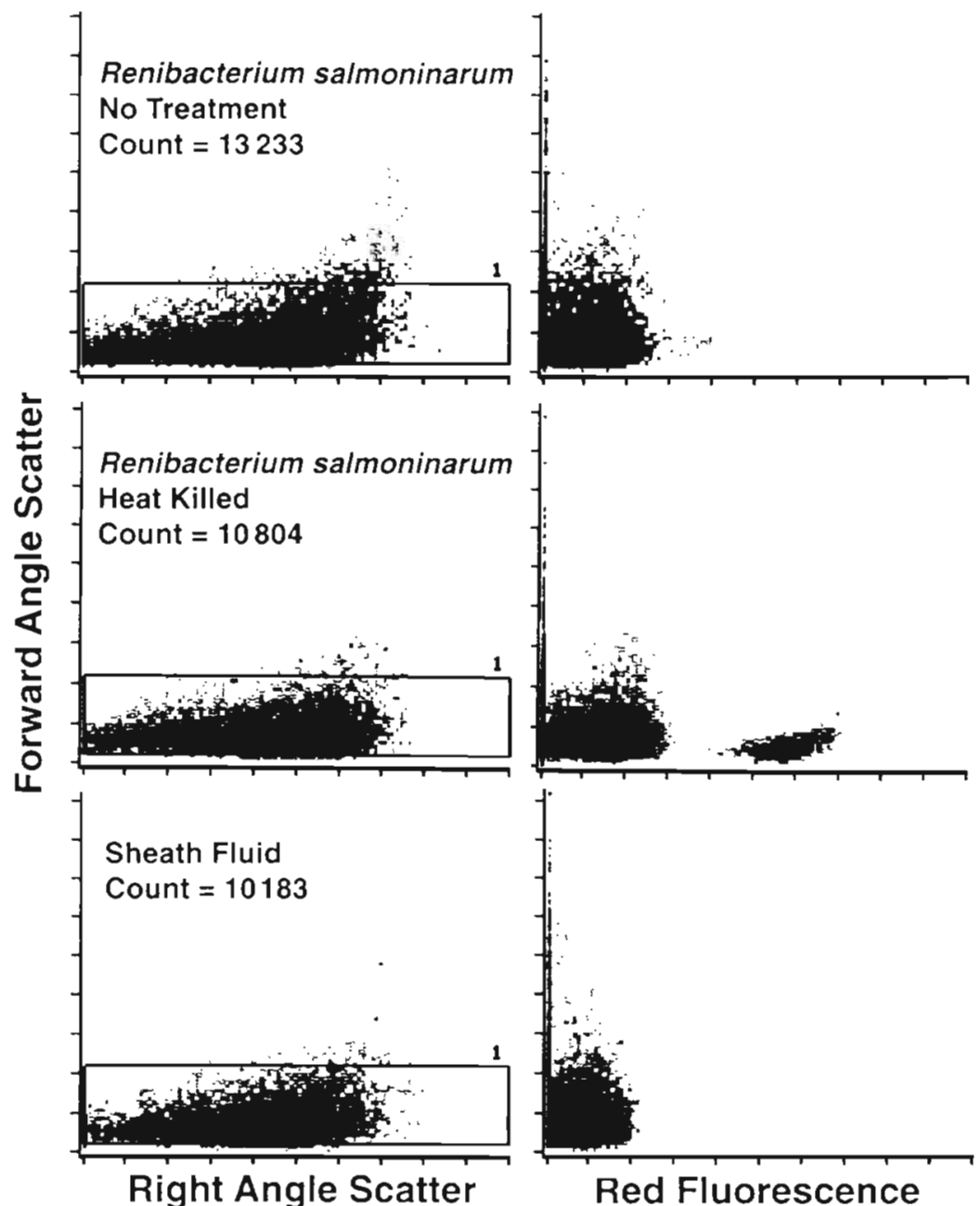

\section{Development of a two-color immunofluorescence flow cytometric assay}

To more accurately gate the Renibacterium salmoninarum cells from background noise when assessing their viability, a 2-color immunofluorescence procedure using FITC-IgG and PI was selected for further testing. The bacteria in each experimental suspension were simultaneously stained with FITC-IgG and exposed to PI. The green fluorescence emitted by the bound conjugate was a signal to the detection system in the flow cytometer that an $R$. salmoninarum cell was passing in the stream of sheath fluid.

Fig. 2. Effect of the dilution of FITC-IgG on the differentiation of live and dead Renibacterium salmoninarum cells by FC. A suspension containing equal numbers of live and dead cells was incubated with 1 dilution of FITC-IgG and PI at a final concentration of $5 \mu \mathrm{g}$ $\mathrm{ml}^{-1}$ for $60 \mathrm{~min}$ at $15^{\circ} \mathrm{C}$. The red fluorescence intensity profile for the $1: 80(\mathrm{v} / \mathrm{v})$ dilution of the FITC-IgG is not shown. Channel 101 $(\Delta)$ is the beginning of the region of HFRI, and any bacteria with an HFRI ( $\geq$ channel 101) were categorized as dead
Fig. 1. Cytograms for untreated and heat-killed Renibacterium salmoninarum cells, and sheath fluid only. Forward angle versus right angle light scatter and PI red fluorescence intensity. The final concentration of PI was $5 \mu \mathrm{g} \mathrm{ml}^{-1}$ The number of detections represented in each cytogram for the area designated by the box (Region 1) is given with the corresponding treatment designation

\section{Dilution of the FITC-IgG}

Analysis by 2 -color fluorescence of a suspension containing equal amounts of untreated and heat-killed bacteria showed that the dilution of FITC-IgG affected the accuracy of the red fluorescence measurements, and consequently, discrimination of live from dead bacteria. The predicted red fluorescence profile contained 2 peaks, one representing relatively weak fluorescence intensities or live bacteria, and one comprised of dead cells with very high red fluorescence intensities. The highest tested concentration $(1: 20 \mathrm{v} / \mathrm{v})$ of the FITC-IgG gave the poorest resolution of the 2 peaks (Fig. 2). The peaks became more distinct as the concentration of FITC-IgG was decreased. A CS analysis based upon red fluorescence profiles of the untreated bacteria stained with PI at $5 \mu \mathrm{g} \mathrm{m} \mathrm{ml}^{-1}$ and the appropriate dilution of FITC-IgG indicated that a conjugate dilution of at least $1: 40(\mathrm{v} / \mathrm{v})$ was required for adequate separation of the peaks. On the basis of the red fluorescence

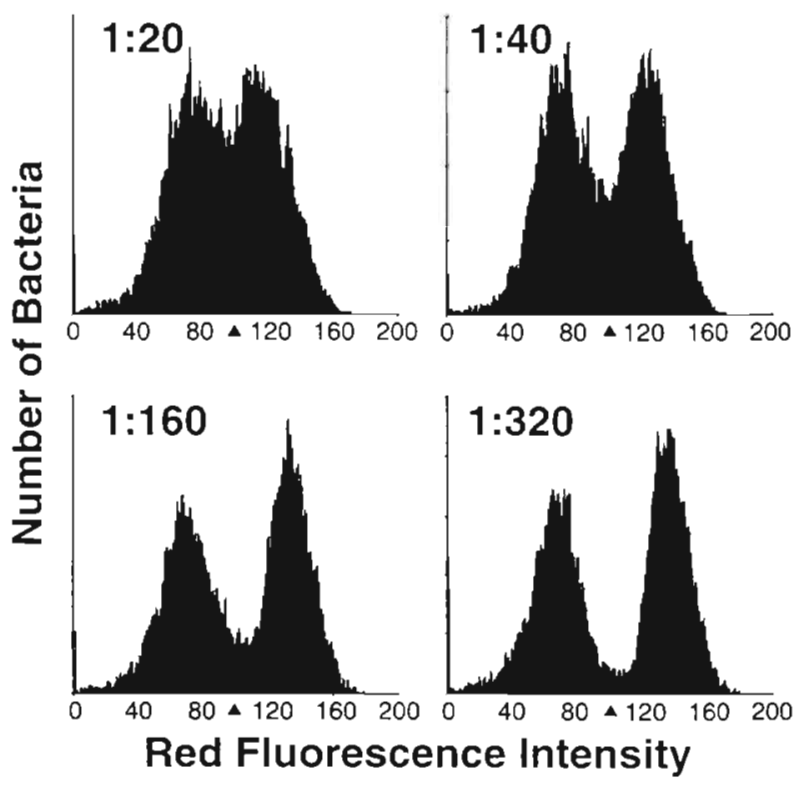


histograms for the FITC-IgG at either a 1:160 or a 1:320 (v/v) dilution, the red high intensity region began at channel 100. The proportions of Renibacterium salmoninarum cells considered dead in the mixed suspensions based upon their red fluorescence intensity exceeding channel 100 were very similar to those obtained by CS analysis. As the FITC-IgG was serially diluted from 1:20 to $1: 320(\mathrm{v} / \mathrm{v})$, the percentages of dead cells according to CS analysis were 45.6, 47.3, $48.4,52.3$, and $52.0 \%$, respectively.

When the red fluorescence profiles of identically stained individual treatment groups of untreated or heat-killed Renibacterium salmoninarum were compared by plotting them on the same histogram, the profiles diverged as the FITC-IgG dilution increased (data noi shuwni. Ayain, maximum separation of the peaks occurred when the conjugate was diluted $1: 160$ or $1: 320(\mathrm{v} / \mathrm{v})$. On the basis of CS analysis, the percentages of dead cells in the heat-killed $R$. salmoninarum suspensions approached the expected level of $100 \%$ as the FITC-IgG concentration decreased; the proportions of $R$. salmoninarum cells categorized as dead in the heat-killed suspension at each conjugate dilution were $94.1 \%$ (at an FITC-IgG dilution of $1: 40[\mathrm{v} / \mathrm{v}]$ ), $96.5 \%(1: 80[\mathrm{v} / \mathrm{v}]), 99.1 \%(1: 160[\mathrm{v} / \mathrm{v}])$, and $99.3 \%$ $(1: 320[\mathrm{v} / \mathrm{v}])$. These proportions correlated with the those obtained when the red fluorescence profiles were divided at channel $100\left(r^{2}=0.99\right)$; the corresponding proportions of $R$. salmoninarum cells considered dead in the heat-killed suspensions were 97.4, 98.6, 99.8, and 99.9\%. Dividing the histograms at channel 100 also suggested that some of the bacteria in the untreated preparations were dead ( 1.35 to $3.51 \%)$, and that a percentage of the bacteria in the heattreated preparations were not stained with propidium iodide $(0.12$ to $2.56 \%)$. These phenomena were represented by the overlap in the red fluorescence intensity profiles for the untreated and heated preparations at each dilution of FITC-IgG; the minimum overlap occurred when the FITC-IgG was diluted 1:320 (v/v). On the basis of the results from testing the untreated and heat-killed $R$. salmoninarum preparations individually or as mixed suspensions, a 1:320 (v/v) final dilution of the FITC-IgG conjugate was selected to be used for FC in conjunction with PI at $5 \mathrm{\mu g} \mathrm{ml}^{-1}$. Channel 101 was assigned as the beginning of the region of high red fluorescence intensity (HRFI), and any bacteria with an HRFI ( $\geq$ channel 101) were categorized as dead.

\section{Standardization with fluorescent carboxylate microspheres}

The addition of $5.75 \mu \mathrm{m}$ fluorescent carboxylate microspheres to each bacterial suspension was investigated as a method to standardize the analyses, and to

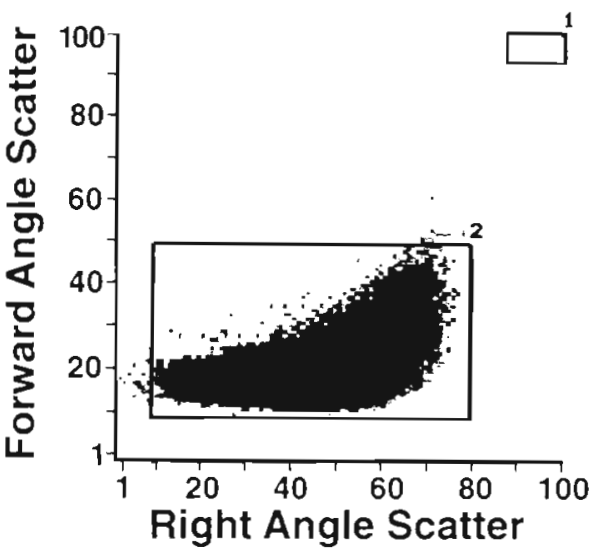

Fig. 3. Cytogram showing differentiation between $5.75 \mu \mathrm{m}$ fiuorescent carboxylate microspheres (Region 1) and Renibacterium salmoninarum cells (Region 2)

permit accounting for disintegration (disappearance of organisms) as a product of lethal exposure. These microspheres, which could be distinguished from Renibacterium salmoninarum by their size (Fig. 3), contained a dye that has excitation and emission maxima very near that of FITC and is matched to the $525 / 30 \mathrm{~nm}$ emission filter. A constant number of microspheres was added to each control or treatment bacterial suspension, then the FITC-labelled $R$. salmoninarum cells were tabulated during the time required for a preselected number of fluorescent microspheres to pass the detector.

The experimental step at which the beads were added to an Renibacterium salmoninarum suspension affected the variability in the number of bacterial cells counted among replicate samples. Fluorescent microspheres were added to identical suspensions of $R$. salmoninarum at $5 \times 10^{6}$ bacteria $\mathrm{ml}^{-1}$ before or after control or chlorine treatments, then the number of bacteria was tabulated during the period necessary for detection of 2000 fluorescent microspheres; the ratio of bacteria to microspheres was $200: 1$, and the chlorine treatment groups were exposed to a starting concentration of $1 \mathrm{mg} \mathrm{l}^{-1}$ free chlorine for $20 \mathrm{~min}$ at $15^{\circ} \mathrm{C}$. When the beads were added before the $R$. salmoninarum cells were divided into the control and chlorine treatment groups, the variability among the replicates in the control and chlorine-treatment groups was 15.9 and $7.1 \%$, respectively. The variability among the replicates in the same groups was 4.0 and $3.9 \%$ when the beads were added after treatment and before being aliquoted into the tubes for staining and replicate analysis by FC. For all subsequent experiments the fluorescent microspheres were added to the $R$. salmoninarum suspensions after treatment, but before being aliquoted into the replicate tubes for addition of the PI and FITC-IgG. 
Variation in the red fluorescence intensity profile for untreated Renibacterium salmoninarum

The interassay variation of the red fluorescence intensity profile for untreated Renibacterium salmoninarum was examined by analyzing bacteria from suspensions prepared on 3 dates with the final 2-color imunofluorescence procedure. The cytogram for forward angle versus right angle light scatter was aligned near channel 60 and the size of region 2 was adjusted to ensure that at least $95 \%$ of the bacteria were included in the analysis. Each suspension was adjusted to $5 \times 10^{7}$ bacteria $\mathrm{ml}^{-1}$ and the bacteria were analyzed as a predetermined number of fluorescent microspheres passed the detector. Flow cytometry results suggested that the method used in this study to prepare $R$. salmoninarum cells for heat or chlorine treatment yielded a population of bacteria that had a predictable red fluorescence intensity distribution (Fig 4), A comparison of the mean red fluorescence profiles among the 3 experimental days by the chi-square test or the Kolmogorov-Smirnov test was not possible because of the large number of bacteria analyzed from each suspension (>160000 R. salmoninarum) resulted in significant differences between replicate samples from the same preparation.

\section{FC assessment of the inactivation of Renibacterium salmoninarum exposed to chlorine}

The final 2-color immunofluorescence assay was then evaluated as a method to describe the inactivation of Renibacterium salmoninarum by chlorine. For each evaluation the red fluorescence profiles of control groups of $R$. salmoninarum cells (untreated or heated at $80^{\circ} \mathrm{C}$ for $20 \mathrm{~min}$ ) were compared with bacteria from the same suspension that had been exposed to chlorine. The flow cytometric assessments, and the corresponding bacteriological culture data, for 2 representative exposures of $R$. salmoninarum to chlorine are summarized in Table 1 . The assessments were done under experimental conditions that differed with regard to the concentration of $R$. salmoninarum cells, initial concentration of chlorine, and duration of chlorine exposure. In one assessment a relatively high concentration of $R$. salmoninarum $\left(8.65 \times 10^{6}\right.$ bacteria ml $\left.{ }^{-1}\right)$ was exposed to chlorine at an initial level of $1 \mathrm{mg} \mathrm{l}^{-1}$ for periods from 1 to 20 min (high-Rs assessment), and in the second assessment the concentration of $R$. salmoninarum was reduced 5 -fold to $1.76 \times 10^{6}$ bacteria $\mathrm{ml}^{-1}$ and exposed to an initial level of $0.8 \mathrm{mg} \mathrm{l}^{-1}$ free chlorine for periods from $20 \mathrm{~s}$ to $5 \mathrm{~min}$ (reduced-Rs assessment). The mean red fluorescence intensity of the profile for each chlorine-exposure group was significantly

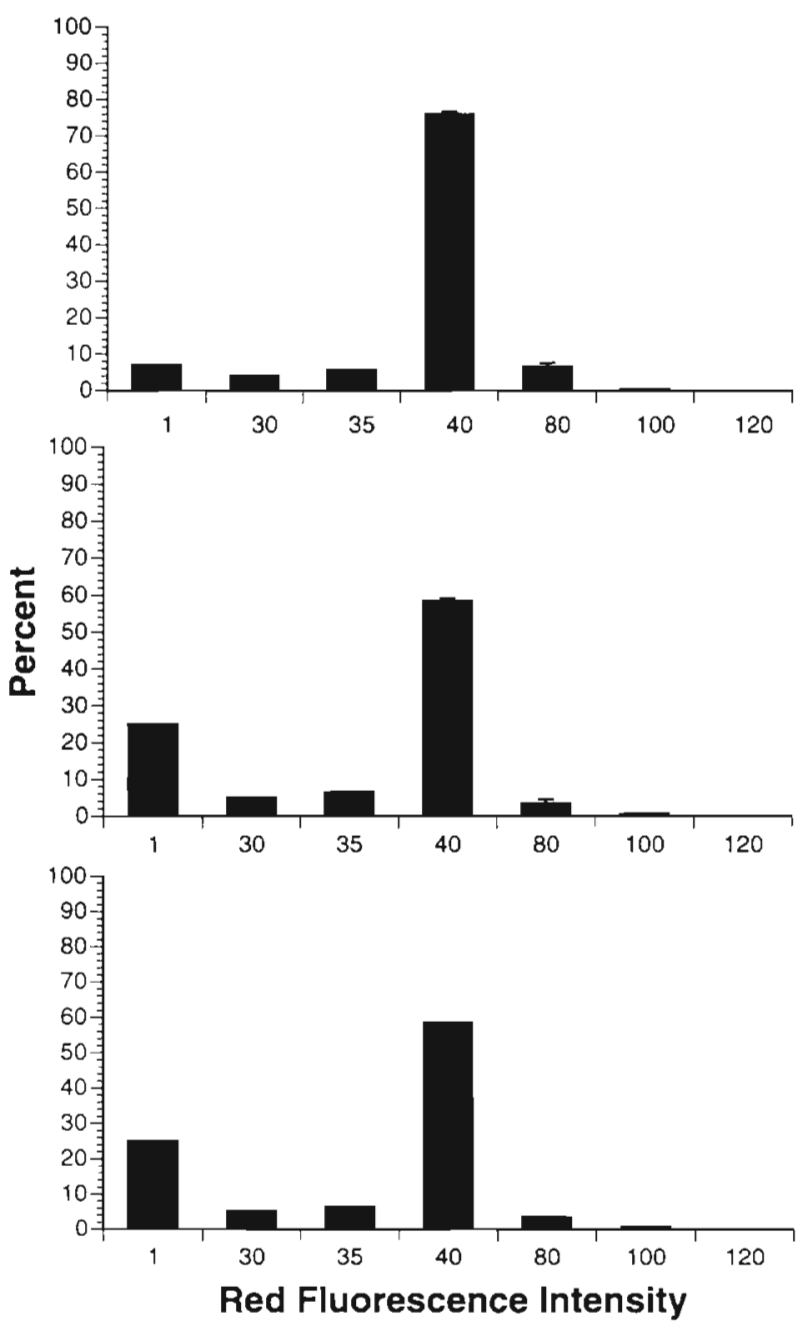

Fig. 4. Histograms of mean red fluorescence intensity distributions for untreated Renibacterium salmoninarum prepared on 3 dates. Bars represent 1 standard deviation. Four replicate samples from each preparation were analyzed by FC after the bacteria were stained with PI and FITC-IgG for $60 \mathrm{~min}$ at $15^{\circ} \mathrm{C}$. The final concentration of PI was $5 \mu \mathrm{g} \mathrm{ml}^{-1}$, and the final dilution of FITC-IgG was $1: 320(\mathrm{v} / \mathrm{v})$

higher than that for the untreated control in the highRs assessment ( $p<0.0001$; Fig. 5). In the low-Rs assessment, the mean red fluorescence intensities of the exposure groups were significantly higher than that for the untreated control only when the $R$. salmoninarum were exposed to chlorine for at least $1 \mathrm{~min}(\mathrm{p} \leq 0.01$; Fig. 6). On the basis of the HRFI and CS analyses, the proportion of dead cells generally increased with the duration of chlorine exposure in both assessments. Whereas the rates of inactivation derived from those analyses did not correlate with the duration of exposure in the high-Rs assessment $\left(r^{2} \leq 0.27\right)$, there was a strong correlation in the reduced-Rs assessment between either estimate and the duration of exposure $\left(r^{2} \geq 0.92\right)$. In both Rs assessments, there was an 
Table 1. Comparison of FC and bacteriological culture measurements of the inactivation of Renibacterium salmoninarum by heat or chlorine at $15^{\circ} \mathrm{C}$. There were 4 replicate red fluorescence intensity (RFI) profiles for each treatment

\begin{tabular}{|c|c|c|c|c|}
\hline \multirow[t]{3}{*}{ Treatment } & \multirow{3}{*}{$\begin{array}{l}\text { Free } \\
\text { chlorine } \\
\left(\mathrm{mg} \mathrm{l}^{-1}\right)^{a}\end{array}$} & \multicolumn{3}{|c|}{ — Mean (SD) inactivation $(\%)$} \\
\hline & & \multicolumn{2}{|c|}{$\longrightarrow \mathrm{RFI}^{\mathrm{b}}$} & \multirow{2}{*}{$\begin{array}{l}\text { Bacterio- } \\
\text { logical } \\
\text { culture }\end{array}$} \\
\hline & & $\begin{array}{l}\text { High RFI } \\
\text { (HFRI) }\end{array}$ & $\begin{array}{l}\text { Curve sub- } \\
\text { traction (CS) }\end{array}$ & \\
\hline \multicolumn{5}{|c|}{$\begin{array}{l}\text { (A) High-Rs assessment. } \\
\text { R. salmoninarum concentration } 8.65 \times 10^{6} \mathrm{ml}^{-1}\end{array}$} \\
\hline \\
\hline Heat $\left(80^{\circ} \mathrm{C}\right)$ & $N^{d}$ & - & - & 100 \\
\hline No treatment & NA & $2.15(0.12)$ & - & - \\
\hline \multicolumn{5}{|c|}{ Chlorine exposure: } \\
\hline $1 \mathrm{~min}$ & 0.66 & $.34 .96(1.1 .5)$ & $64.82(120)$ & 99.999 \\
\hline $3 \mathrm{~min}$ & 0.65 & $82.74(4.32)$ & $93.00(1.62)$ & 99.998 \\
\hline $5 \mathrm{~min}$ & 0.61 & $91.07(3.93)$ & $96.47(1.47)$ & 99.999 \\
\hline $10 \mathrm{~min}$ & 0.54 & $85.45(3.31)$ & $94.54(1.58)$ & 100 \\
\hline $20 \mathrm{~min}$ & 0.46 & $86.14(2.92)$ & $95.09(1.45)$ & 100 \\
\hline \multicolumn{5}{|c|}{$\begin{array}{l}\text { (B) Reduced-Rs assessment. } \\
R \text {. salmoninarum concentration } 1.76 \times 10^{6} \mathrm{ml}^{-1}\end{array}$} \\
\hline \multicolumn{5}{|c|}{ Controls: } \\
\hline Heat $\left(80^{\circ} \mathrm{C}\right)$ & $N A^{d}$ & - & - & 100 \\
\hline No treatment & NA & $11.46(0.82)$ & - & - \\
\hline \multicolumn{5}{|c|}{ Chlorine exposure: } \\
\hline $20 \mathrm{~s}$ & 0.66 & $12.30(0.73)$ & $2.67(2.62)$ & 99.957 \\
\hline $40 \mathrm{~s}$ & 0.53 & $14.15(0.44)$ & $5.53(2.43)$ & 99.999 \\
\hline $1 \mathrm{~min}$ & 0.47 & $16.36(0.64)$ & $9.94(1.72)$ & 100 \\
\hline $2 \mathrm{~min}$ & 0.43 & $50.38(4.05)$ & $54.01(6.11)$ & 100 \\
\hline $3 \mathrm{~min}$ & 0.40 & $79.19(4.57)$ & $80.47(3.17)$ & 100 \\
\hline $5 \mathrm{~min}$ & 0.38 & $97.78(1.88)$ & $98.40(1.10)$ & 100 \\
\hline \multicolumn{5}{|c|}{$\begin{array}{l}{ }^{a} \text { The initial concentrations of free chlorine in the high-Rs and the } \\
\text { reduced-Rs assessments were } 1.0 \text { and } 0.8 \mathrm{mg} \mathrm{l}^{-1} \text {, respectively }\end{array}$} \\
\hline \multicolumn{5}{|c|}{$\begin{array}{l}\text { b The proportion of inactivated } R \text {. salmoninarum cells in each replicate } \\
\text { of a treatment was calculated on the basis of the corresponding repli- } \\
\text { cate of the heat-control group. }\end{array}$} \\
\hline \multicolumn{5}{|c|}{ High-Rs assessment: } \\
\hline \multicolumn{5}{|c|}{$\%$ Inactivation $_{i j}=\frac{\text { Treatment, } \text { Replicate }}{\text { Heated }\left(80^{\circ} \mathrm{C}\right) \text { control replicate }} \times 100$} \\
\hline \multicolumn{5}{|c|}{$\begin{array}{l}\text { The mean (SD) percentage of dead bacteria in the heat-control group } \\
\text { based upon HRFI analysis was } 93.18(1.48) \text {, and } 93.75(0.52) \text { based } \\
\text { upon CS analysis. }\end{array}$} \\
\hline \multicolumn{5}{|c|}{ Reduced-Rs assessment: } \\
\hline \multicolumn{5}{|c|}{$\%$ Inactivation $_{i j}=\frac{\text { Treatment }_{1} \text { Replicate }_{j}}{\text { Heated }\left(80^{\circ} \mathrm{C}\right) \text { control }} \times 100$} \\
\hline \multicolumn{5}{|c|}{$\begin{array}{l}\text { The percentage of dead bacteria in the heat-control group based upon } \\
\text { the HRFI analysis was } 83.89 \% \text {, and } 73.53 \% \text { based upon CS analysis; } \\
\text { these percentages are based on a single determination }\end{array}$} \\
\hline \multicolumn{5}{|c|}{$\begin{array}{l}{ }^{\mathrm{C}} \text { No standard deviation was calculated for these percentages; the num- } \\
\text { bers of } R \text {. salmoninarum colonies on each of } 4 \text { replicate agar plates at } \\
\text { the appropriate dilution were averaged }\end{array}$} \\
\hline 'Not applicable & & & & \\
\hline
\end{tabular}

extremely rapid loss by $R$. salmoninarum of its ability grow in bacteriological culture following exposure to chlorine; neither the duration of exposure nor the HRFI and CS inactivation estimates correlated with the results of bacteriological culture $\left(r^{2} \leq 0.22\right)$. In both assessments, there was a correlation between the estimates of inactivation based upon the HRFI and CS analyses $\left(r^{2}>\right.$ 0.99 ).

For each control and chlorine-treatment group in the high-Rs assessment, the replicate red fluorescence profiles were made from the Renibacterium salmoninarum cells that passed the detectors during the period required to count 1000 tluorescent microspheres. Although the time necessary to detect that number of fluorescent microspheres ranged from 28 to $36 \mathrm{~s}$ among the 28 analyses in this investigation, there was no correlation between the time necessary to count 1000 fluorescent microspheres and the total number of $R$. salmoninarum cells detected and analyzed $\left(\mathrm{r}^{2}=0.40\right)$. The mean numbers of bacteria detected in the chlorine-treatment groups and the control group that received the lethal heat treatment, however, were significantly lower than that for the untreated control group ( $p<0.01$; Table 2). The changes in the mean numbers of bacteria analyzed did not correlate with the duration of exposure, and there were no significant differences in the mean counts among the chlorine exposure groups ( $p>0.05$ ).

\section{DISCUSSION}

In this report, we have described the development of a flow cytometric technique that uses PI staining to quantify the proportions of living and dead bacterial cells in a Renibacterium salmoninarum population.

As a prerequisite to flow cytometric livedead discrimination, we found that it was necessary to label Renibacterium salmoninarum with FITC-IgG to permit the bacterium to be accurately identified for analysis. The relatively small size, and possibly the diplococcoid morphology, of $R$. salmoninarum contributed to errors in gating the bacterium strictly on the basis of right angle and forward light scatter. The accuracy of the light scatter measurements was 

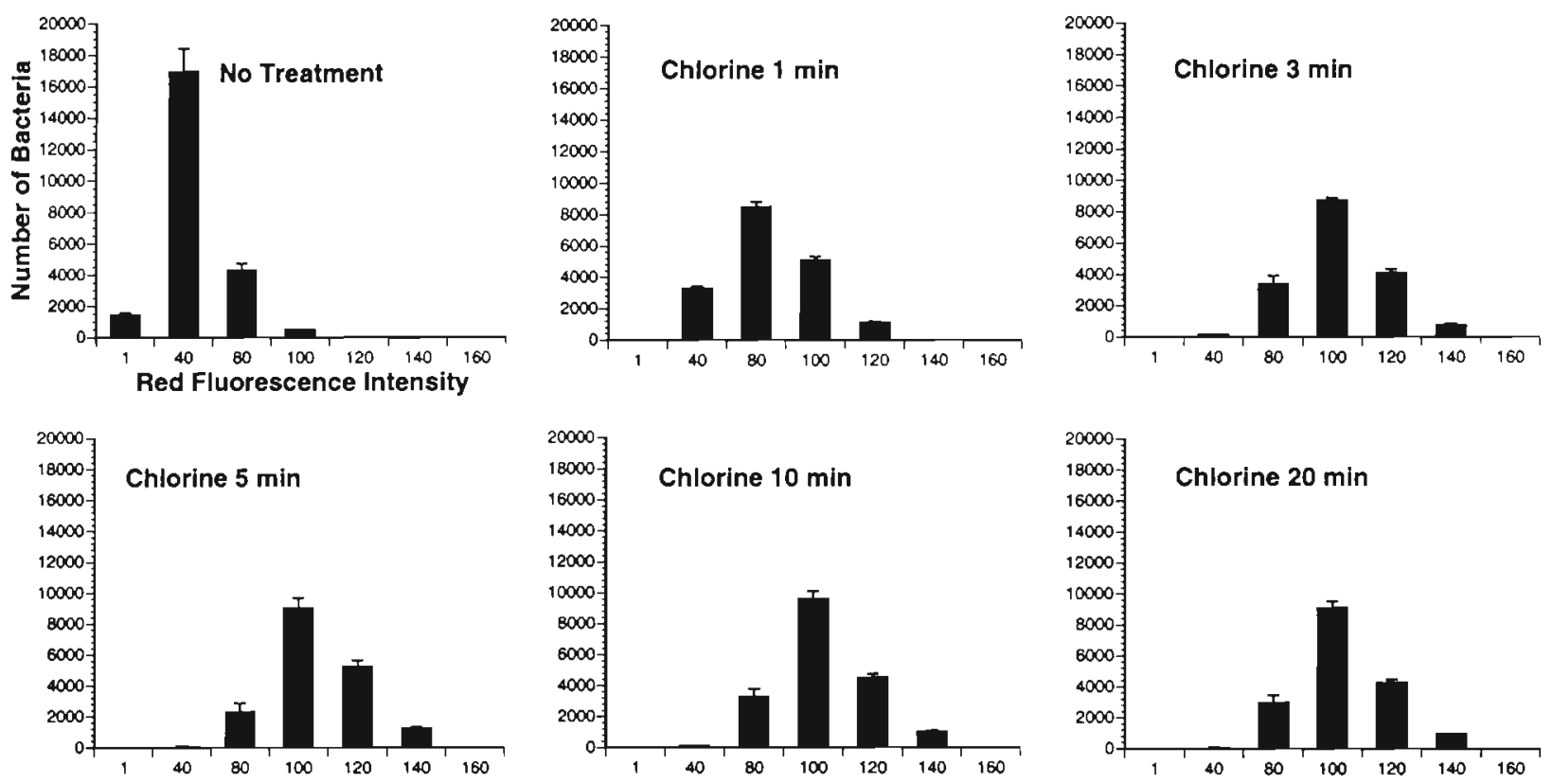

Fig. 5. Red fluorescence intensity histograms for suspensions of Renibacterium salmoninarum in the high-Rs assessment groups. Bacteria were analyzed by FC after receiving no treatment, or after exposure to chlorine for 1 to 20 min at $15^{\circ} \mathrm{C}$. The concentrations of free chlorine are shown in Table 1A. The bacteria in each preparation were stained with PI and FITC-IgG for 60 min at $15^{\circ} \mathrm{C}$. The final concentration of PI was $5 \mu \mathrm{g} \mathrm{m}^{-1}$, and the final dilution of FITC-IgG was 1:320 (v/v). The concentration of $R$. salmoninarum in each suspension was $8.65 \times 10^{6}$ bacteria $\mathrm{ml}^{-1}$. The channel at which the mean (SD) red fluorescence intensity occurred in each control or treatment group was as follows: no treatment $66.78(0.21)$; chlorine for 1 min 93.70 (0.22); chlorine for $3 \mathrm{~min} 111.80$ (1.19); chlorine for $5 \mathrm{~min} 115.65(1.14)_{\text {; }}$ chlorine for $10 \mathrm{~min} 112.98(0.99)$; and chlorine for $20 \mathrm{~min} 113.08(0.83)$

principally affected by the extreme gain settings necessary for resolving such a small bacterium with the Ortho $50 \mathrm{H}$ flow cytometer. Other reports have described similar problems associated with bacterial morphology in resolving certain bacteria from electronic noise, or distinguishing between bacterial species, by flow cytometric methods (Barnett et al. 1984, Donnelly \& Baigent 1986, Monfort \& Baleux 1992).

Table 2. Duration of analysis necessary for 1000 fluorescent microspheres to be tabulated by the flow cytometer, and the number of Renibacterium salmoninarum cells detected during that period. There were 4 replicate determinations for each control or treatment group

\begin{tabular}{|c|c|c|c|}
\hline \multirow[t]{2}{*}{ Group } & \multicolumn{2}{|c|}{ Duration (s) } & \multirow{2}{*}{$\begin{array}{l}\text { R. salmoni- } \\
\text { narum cells } \\
\text { Mean (SD) }\end{array}$} \\
\hline & Range & Mean (SD) & \\
\hline \multicolumn{4}{|l|}{ Controls: } \\
\hline Heat $\left(80^{\circ} \mathrm{C}\right)$ & $29-35$ & $32.25(2.50)$ & $12502(1163)$ \\
\hline No treatment & $30-34$ & $32.25(1.71)$ & 23245 (1929) \\
\hline \multicolumn{4}{|c|}{ Chlorine exposure: } \\
\hline $1 \mathrm{~min}$ & $31-36$ & $32.75(2.22)$ & $18173(663)$ \\
\hline $3 \mathrm{~min}$ & $29-33$ & $31.25(1.71)$ & $17209(263)$ \\
\hline $5 \mathrm{~min}$ & $29-32$ & $30.25(1.50)$ & $17970(1399)$ \\
\hline $10 \mathrm{~min}$ & $32-35$ & $33.25(1.50)$ & $18647(908)$ \\
\hline $20 \min$ & $29-34$ & $31.50(2.08)$ & $17428(854)$ \\
\hline
\end{tabular}

Staining the surface antigens of Renibacterium salmoninarum with an appropriate amount of FITC-IgG was directly correlated with the resolution of the red fluorescence profiles for untreated and killed bacteria by FC. Because there is some overlap in the red regions of the emission spectra for FITC and PI, the detector for the red fluorescence of PI will also detect some fluorescence that is actually contributed by FITC (Parks et al. 1986). When FITC-IgG was used at high concentrations, this contribution was sufficient to shift the mean red fluorescence profile for the untreated $R$. salmoninarum significantly toward the region of HRFI.

The mean counts of Renibacterium salmoninarum labelled with the FITC-IgG decreased among bacterial preparations exposed to heat or chlorine, suggesting that the cellular structure was damaged by these treatments. Severe disruption of the cell wall may have resulted in bacterial fragments still capable of binding the FITC-IgG, but too small to be detected by the flow cytometer. Longer durations of chlorine exposure would probably cause disruption of higher proportions of bacteria, yet the counts did not decrease relative to the length of exposure. These data suggest that a large subpopulation of the $R$. salmoninarum cells (i.e., ca $30 \%$ as affected by chlorine; ca $50 \%$ as affected by heat) may have been more susceptible to lethal treatment, e.g., oxidation by chlorine, because of their age 

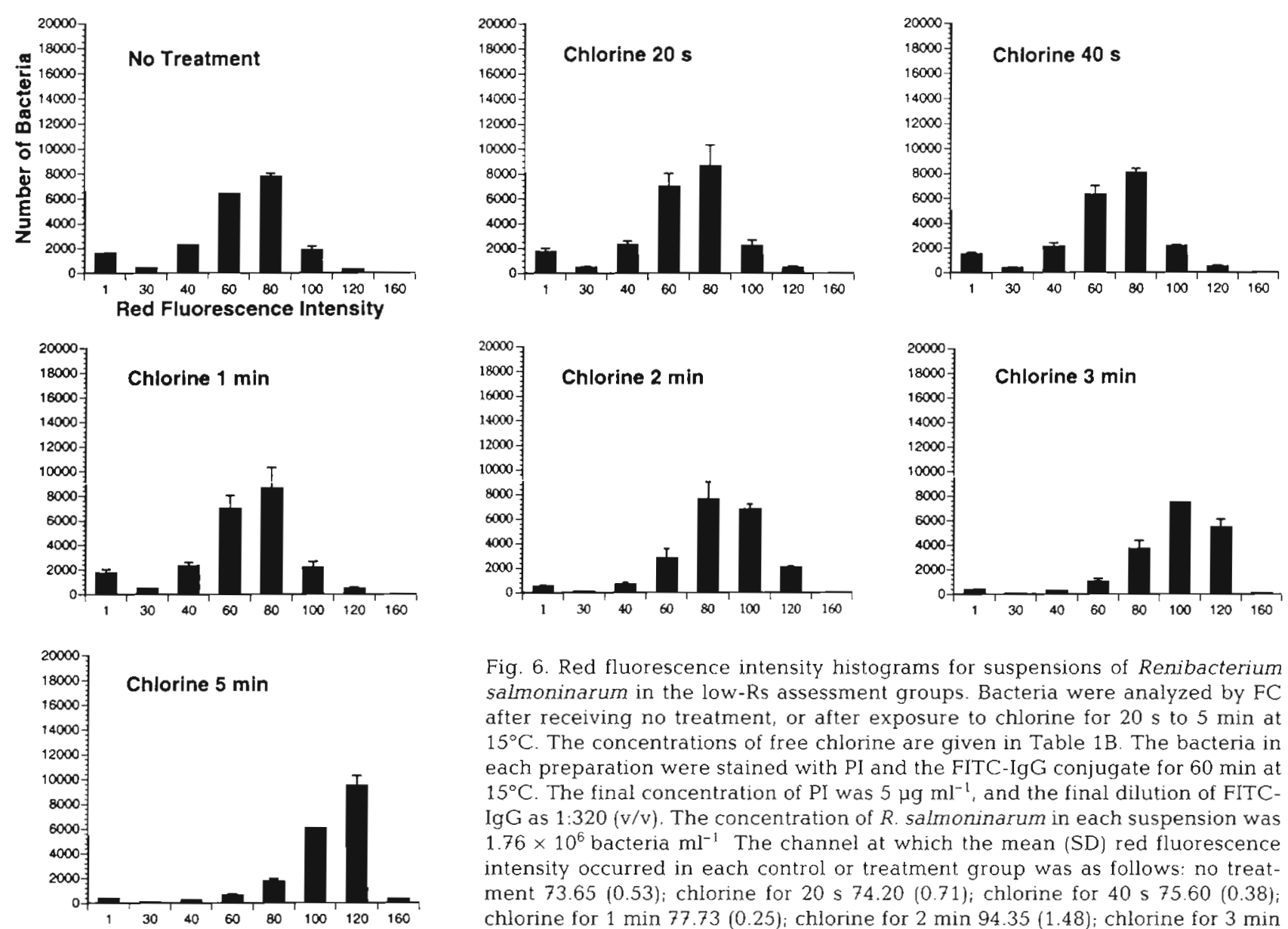

Fig. 6. Red fluorescence intensity histograms for suspensions of Renibacterium salmoninarum in the low-Rs assessment groups. Bacteria were analyzed by FC after receiving no treatment, or after exposure to chlorine for $20 \mathrm{~s}$ to $5 \mathrm{~min}$ at $15^{\circ} \mathrm{C}$. The concentrations of free chlorine are given in Table $1 \mathrm{~B}$. The bacteria in each preparation were stained with PI and the FITC-IgG conjugate for $60 \mathrm{~min}$ at $15^{\circ} \mathrm{C}$. The final concentration of PI was $5 \mu \mathrm{g} \mathrm{ml}^{-1}$, and the final dilution of FITCIgG as $1: 320(\mathrm{v} / \mathrm{v})$. The concentration of $R$. salmoninarum in each suspension was $1.76 \times 10^{6}$ bacteria $\mathrm{ml}^{-1}$ The channel at which the mean (SD) red fluorescence intensity occurred in each control or treatment group was as follows: no treatment 73.65 (0.53); chlorine for $20 \mathrm{~s} 74.20(0.71)_{\text {i }}$ chlorine for $40 \mathrm{~s} 75.60(0.38)_{i}$ chlorine for $1 \mathrm{~min} 77.73(0.25)$; chlorine for $2 \min 94.35(1.48)$; chlorine for $3 \mathrm{~min}$ 105.88 (1.76); and chlorine for $5 \min 116.18(1.01)$

or random structural defects, resulting in the loss of approximately equal proportions of cells in each chlorine-exposure group.

Whereas the use of the 2-color fluorescence procedure appeared promising for delineating live from dead cells, neither the PI nor the FITC-IgG allowed direct identification of cells that had been inactivated by heat or chlorine treatments, particularly when the FC protocol was standardized by counting a constant number of bacteria from each preparation. Modifying the FC protocol to analyze bacteria over a uniform period of time was also found to be inappropriate because the bacteria passed the detectors at variable rates. Consequently, the addition of fluorescent carboxylate microspheres to each bacterial suspension was adopted to standardize the analyses.

The detection of intact dead Renibacterium salmoninarum cells by fluorescence FC relied upon those cells loosing their membrane integrity, and thus becoming permeable to a fluorescent exclusion dye. PI was selected for this study because it is the recommended exclusion dye for testing membrane integrity (Shapiro 1988); the fluorescence of PI may actually increase sev- eral-fold after it intercalates with a double-stranded nucleic acid (Krishan et al. 1978). Under the conditions of this study, the oxidative action of chlorine was contributed by hypochlorous acid, a chlorine species with potent germicidal activity that is related to its ability to penetrate a microorganism's membrane (Haas \& Englebrecht 1980). A range of physiological effects on aquatic microorganisms has been correlated with the biocidal effectiveness of chlorine, including action on one or more metabolic pathways and damage to an organism's DNA (Breisch et al. 1984). Haas \& Englebrecht (1980) investigated mechanisms that might be responsible for the lethal effects of chlorine on Escherichia coli, Mycobacterium fortuitum, and Candida parapsilosis. These authors found that the effects of aqueous chlorine were dependent upon its action on the cell membrane and passage into the cell, followed by damage to the DNA. The red fluorescence intensity of a particular $R$. salmoninarum will be dependent upon passage of the PI past the cell wall and the intercalating of the dye at sites on the double-stranded nucleic acids. The latter should correlate with the amount of double-stranded nucleic acid present, and 
possibly the opening of additional binding sites by the action of chlorine. The amount of double-stranded nucleic acid was not uniform among individual $R$. salmoninarum cells in the control or treatment groups because the nucleic acid content of a bacterium is dependent upon its growth rate (Birge 1988). Because of the uniform conditions used for the preparation of test cultures, approximately equal numbers of cells in the different reproductive states should have been present in each group, and changes in the red fluorescence intensity distributions could be attributed to the action of chlorine.

The mean red fluorescence intensity of the Renibacterium salmoninarum chlorine-treatment groups increased with the duration of exposure to chlorine. The results of this study suggested that the concentration of free chlorine or the number of bacteria may have also affected the magnitude of those increases. Only in the reduced-Rs assessment did the proportions of dead cells based upon the HRFI and CS analyses correlate with the duration of chlorine exposure. The PI fluorescence intensity profile of human fibroblast DNA has also been reported to change following a nonlethal oxidative stress by free radicals (Le Goff et al. 1992).

Clearly, when based upon bacteriological culture, the rate of Renibacterium salmoninarum inactivation by chlorine was much faster than suggested by either the HRFI or CS analyses. The cellular functions necessary for $R$. salmoninarum to replicate and form colonies on agar plates may be much more sensitive to chlorination than are the biophysical characteristics associated with the entry and binding of PI. The critical issue here is ultimately whether membrane damage as indicated by PI-emitted red fluorescence or culturability by the standard plate assay is more closely related to the potential infectivity of $R$. salmoninarum to salmonids. With only data from a single study available (Pascho et al. 1995), relying on membrane damage would produce a more conservative result and less likelihood of underestimation of disinfection requirements to protect fish from infection.

In an earlier study, Pascho et al. (1995) provided evidence that some Renibacterium salmoninarum within bacterial aggregates may be protected from the bactericidal effects of chlorine. It is possible that the discrepancies between the inactivation estimates based upon red fluorescence and bacteriological culture were also caused by the presence of $R$. salmoninarum injured by sublethal chlorine levels within the aggregates. The definition of a dead microbe varies among reports, and this may be a bacterium that has lost all metabolic activity and still possesses an intact cell wall (Mason et al. 1986), or one that has simply lost the ability to multiply under suitable growth conditions (Davis \& Dulbecco 1973, Postgate 1976, Kurath \& Morita 1983).
Some Gram-positive and Gram-negative bacteria that are stressed or injured by chemical treatment can recover and resume growth under suitable conditions (Hurst 1977, Camper \& McFeters 1979, Flowers \& Ordal 1979, Ray 1979, Kaprelyants \& Kell 1992). The Gram-negative fish pathogenic bacterium Aeromonas salmonicida has been reported to enter a nonculturable state under low-nutrient conditions (Morgan et al. 1991). Whereas the inactivation of $R$. salmoninarum in this study was presumed to be a result of cell death, the chlorine may have sublethally damaged a proportion of the cells. These bacteria may have been unable to form colonies on agar plates, yet retained enough metabolic activity to remain impermeable to an exclusion dye. Injured bacteria may have also died during the recovery phase. Because such problems create uncertainty in distinguishing dead from live unicellular organisms, Postgate (1976) cautioned that rapid assessment of cell death with vital stains is only appropriate when the microorganism has been subjected to a 'catastrophic' stress. In both assessments of this study, the best agreement between the red fluorescence intensity estimations and bacteriological culture occurred in groups of $R$. salmoninarum that had been exposed to chlorine for relatively long durations (several minutes)

Bacteriological culture is the only quantitative method currently available for routinely determining the proportions of viable Renibacterium salmoninarum in such groups, but the slow growth of the bacterium limits the usefulness of culture as a research tool. In contrast, selected attributes of microorganisms can be described by FC with such speed that thousands of cells in a test group can be evaluated in a single analysis. The speed and flexibility of FC potentially make it an ideal alternative to bacteriological culture for any $R$. salmoninarum investigation requiring an immediate viability assessment of a test population. In addition, multicolor analysis of the $R$. salmoninarum preparations with FITC-IgG and PI in this study further simplified the assessment because both dyes can be excited with an argon laser.

\section{LITERATURE CITED}

American Public Health Association (1989) Standard methods for the examination of water and wastewater, 17 th edn. American Public Health Association, Washington, DC

Barnett JM, Cuchens MA, Buchann W (1984) Automated immunofluorescent speciation of oral bacteria using flow cytometry. J Dent Res 8:1040-1042

Bell GR, Higgs DA, Traxler GS (1984) The effect of dietary ascorbate, zinc, and manganese on the development of experimentally induced bacterial kidney disease in sockeye salmon (Oncorhynchus nerka). Aquaculture 36: $293-311$ 
Benediktsdottir E, Helgason S, Gudmundsdottir S (1991) Incubation time for the cultivation of Renibacterium salmoninarum from Atlantic salmon, Salmo salar L., broodfish. J Fish Dis 14:97-102

Birge EA (1988) Bacterial and bacteriophage genetics: an introduction, 2nd edn. Springer-Verlag, New York

Boye E, Løbner-Olesen A (1991) Bacterial growth control studied by flow cytometry. Res Microbiol 142:131-135

Breisch LL, Wright DA, Powell DM (1984) Chlorine and the Chesapeake Bay. A review of research literature. Maryland Sea Grant Association Pub. UM-SG-TS-84-02, College Park

Bullock GL, Leek SL (1986) Use of erythromycin in reducing vertical transmission of bacterial kidney disease. Vet Hum Toxicol 28 (Suppl 1):18-20

Bullock GL, Stuckey HM, Mulcahy D (1978) Corynebacterial kidney disease: egg transmission following iodophore disinfection. Fish Health News 7:51-52

Bullock GL. Griffin RR. Sturkey HM (1980) Detection of Corynebacterium salmoninus by direct fluorescent antibody test. Can J Fish Aquat Sci 37:719-721

Byrd JJ, Xu HS, Colwell RR (1991) Viable but nonculturable bacteria in drinking water. Appl Environ Microbiol 57: $875-878$

Calabrese JP, Bissonnette GK (1990) Improved membrane filtration method incorporating catalase and sodium pyruvate for detection of chiorine-stressed coliform bacteria. Appl Environ Microbiol 56:3558-3564

Camper AK, MCFeters GA (1979) Chlorine injury and the enumeration of waterborne coliform bacteria. Appl Environ Microbiol 37:633-641

Daly JG. Stevenson RMW (1985) Charcoal agar, a new growth medium for the fish disease bacterium Renibacterium salmoninarum. Appl Environ Microbiol 50:868-871

Davis BD, Dulbecco R (1973) Sterilization and disinfection. In: Davis BD, Dulbecco R, Eisen HN, Ginsberg HS, Wood WB Jr, McCarty $M$ (eds) Microbiology. Harper and Row, Hagerstown, MD, p 1451-1465

Desmonts C, Minet J, Colwell R, Cormier M (1990) Fluorescent-antibody method useful for detecting viable but nonculturable Salmonella spp. in chlorinated wastewater. Appl Environ Microbiol 56:1448-1452

Donnelly CW, Baigent GJ (1986) Method for flow cytometric detection of Listeria monocytogenes in milk. Appl Environ Microbiol 52:689-695

Dupree HK (1981) An overview of the various techniques to control infectious diseases in water supplies and in water reuse aquacultural systems. Bio-engineering symposium for fish culture. FCS (Fish Cult Sect Am Fish Soc) Publ 1: $83-89$

Elliott DG, Barila TY (1987) Membrane filtration-fluorescent antibody staining procedure for detecting and quantifying Renibacterium salmoninarum in coelomic fluid of chinook salmon (Oncorhynchus tshawytscha). Can J Fish Aquat Sci 44:206-210

Elliott DG, Pascho RJ, Bullock GL (1989) Developments in the control of bacterial kidney disease of salmonid fishes. Dis Aquat Org 6:201-215

Evelyn TPT (1977) An improved growth medium for the kidney disease bacterium and some notes on using the medium. Bull Off Int Epiz 87:5-6

Evelyn TPT, Ketcheson JE, Prosperi-Porta L (1986a) Use of erythromycin as a means of preventing vertical transmission of Renibacterium salmoninarum. Dis Aquat Org 2: $7-11$

Evelyn TPT, Prosperi-Porta L, Ketcheson JE (1986b) Experimental intra-ovum infection of salmonid eggs with Reni- bacterium salmoninarum and vertical transmission of the pathogen with such eggs despite their treatment with erythromycin. Dis Aquat Org 1:197-202

Evelyn TPT, Prosperi-Porta L, Ketcheson JE (1990) Two new techniques for obtaining consistent results when growing Renibacterium salmoninarum on KDM2 culture medium. Dis Aquat Org 9:209-212

Flowers RS, Ordal ZJ (1979) Current methods to detect stressed staphylococci. J Food Prot 42:362-367

Fryer JL, Sanders JE (1981) Bacterial kidney disease of salmonid fish. Annu Rev Microbiol 35:273-298

Haas CN, Englebrecht RS (1980) Physiological alterations of vegetative microorganisms resulting from chlorination. J Water Pollut Control Fed 52:1976-1989

Hurst A (1977) Bacterial injury: a review. Can J Microbiol 23 935-944

Jepras RI, Carter J, Pearson SC, Paul FE, Wilkinson MJ (1995) Development of a robust flow cytometric assay for determining numbers of viable bacteria. Appl Environ Míticobiol 61:2696-2701

Kaprelyants AS, Kell DB (1992) Rapid assessment of bacterial viability and vitality by rhodamine 123 and flow cytometry. J Appl Bacteriol 72:410-422

Krishan A, Ganapathi RN, Israel M (1978) Effect of adriamycin and analogs on the nuclear fluorescence of propidium iodide-stained cells. Cancer Res 38:3656-3662

Kurath G, Morita RY (1983) Starvation-survival physiological studies of a marine Pseuodmonas sp. Appl Environ Microbiol 45:1206-1211

Le Goff L, Lapeyrade D, Bossi A, Noel-Hudson MS, Bonaly J Wepierre J (1992) Effect of biophysical changes of propidium iodide access to DNA during oxidative stress of cultured human skin cells. Toxicol In Vitro 6:423-432

López-Amorös R, Comas J, Vives-Rego J (1995) Flow cytometric assessment of Escherichia coli and Salmonella typhimurium starvation-survival in seawater using rhodamine 123, propidium iodide, and oxonol. Appl Environ Microbiol 61:2521-2526

Mason CA, Hamer G, Byers JD (1986) The death and lysis of microorganisms in environmental processes. FEMS Microbiol Rev 39:373-401

Miller JS, Quarles JM (1990) Flow cytometric identification of microorganisms by dual staining with FITC and PI. Cytometry 11:667-675

Mitchum DL, Sherman LE (1981) Transmission of bacterial kidney disease from wild to stocked hatchery trout. Can J Fish Aquat Sci 38:547-551

Monfort P, Baleux B (1992) Comparison of flow cytometry and epifluorescence microscopy for counting bacteria in aquatic ecosystems. Cytometry 13:188-192

Morgan JAW, Cranwell PA, Pickup RW (1991) Survival of Aeromonas salmonicida in lake water. Appl Environ Microbiol 57:1777-1782

Nebe-von Caron G, Stephens P, Badley RA (1998) Assessment of bacterial viability status by flow cytometry and single cell sorting. J Appl Microbiol 84:988-998

Parks DR, Lanier LL, Herzenberg LA (1986) Flow cytometry and fluorescence activated cell sorting (FACS). In: Weir DM (ed) Handbook of experimental immunology, Vol 1. Blackwell Scientific Publications, Boston, p 29.1-29.21

Pascho RJ, Mulcahy D (1987) Enzyme-linked immunosorbent assay for a soluble antigen of Renibacterium salmoninarum, the causative agent of salmonid bacterial kidney disease. Can J Fish Aquat Sci 44:183-191

Pascho RJ, Elliott DG, Streufert JM (1991) Broodstock segregation of spring chinook salmon Oncorhynchus tshawytscha by use of the enzyme-linked immunosorbent assay 
(ELISA) and the fluorescent antibody technique (FAT) affects the prevalence and levels of Renibacterium salmoninarum infection in progeny. Dis Aquat Org 12:25-40

Pascho RJ, Landolt ML, Ongerth JE (1995) Inactivation of Renibacterium salmoninarum by free chlorine. Aquaculture 131:165-175

Postgate JR (1976) Death in macrobes and microbes. In: Gray TRG, Postgate JR (eds) Survival of vegetative microbes. Proc Symp Soc Gen Microbiol 26, Cambridge University Press, Cambridge, p 1-18

Ray B (1979) Methods to detect stressed microorganisms. J Food Prot 42:346-355

Ross AJ, Smith CA (1972) Effect of two iodophores on bacterial and fungal fish pathogens. J Fish Res Board Can 29: $1359-1361$

Roszak DB, Colwell RR (1987) Survival strategies of bacteria in the natural environment. Microbiol Rev 51:365-379

Shapiro HM (1988) Practical flow cytometry, 2nd edn. Alan R Liss, New York

Singh A, Yu FP, McFeters GA (1990) Rapid detection of chlorine-induced bacterial injury by the direct viable count method using image analysis. Appl Environ Microbiol 56: 389-394

Suller MTE, Lloyd D (1999) Fluorescence monitoring of

Editorial responsibility: David Bruno,

Aberdeen, Scotland, UK antibiotic-induced bacterial damage using flow cytometry Cytometry 35:235-241

Thorsen BK, Enger $\varnothing$, Norland S, Hoff KA (1992) Long-term starvation survival of Yersinia ruckeri at different salinities studied by microscopical and flow cytometric methods. Appl Environ Microbioi 58:1624-1628

Turaga PSD, Wiens GD, Kaattari SL (1987) Analysis of Renibacterium Salmoninarum antigen production in situ. Fish Pathol 22:209-214

Van Dilla MA, Langlois RG, Pinkel D, Yajko D, Hadley WK (1983) Bacterial characterization by flow cytometry. Science 220:620-621

Wedemeyer GA (1996) Managing pathogen exposure. In: Wedemeyer GA (ed) Physiology of fish in intensive culture systems. Chapman and Hall, New York, p 202-226

Wedemeyer GA, Nelson NC (1977) Survival of two bacterial fish pathogens (Aeromonas salmonicida and the enteric redmouth bacterium) in ozonated, chlorinated, and untreated waters. J Fish Res Board Can 34:429-432

Wedemeyer GA, Nelson NC, Smith CA (1978) Survival of the salmonid viruses infectious hematopoietic necrosis (IHNV) and infectious pancreatic necrosis (IPNV) in ozonated, chlorinated, and untreated waters. J Fish Res Board Can 35:875-879

Submitted: November 20, 1999; Accepted: March 27, 2000 Proofs received from author(s): June 14, 2000 